I 、はじめに

昭和 57 年 8 月老人保健法が成立し、58年 2 月から施行された。私達はこれまて長村保健 を研究テーマのーつにしていたのて、この機 会に県内て農家率が高く、町も剠心に地域保 健活動を推進している䄄岡罢朝倉郡夜須町を 選び、昭和 57 年から一般住民の健康調查に従 事した。その 10 年にわたる農村地域保煡の立 場からの住民健康管理の歩みを報告する。

II. 夜須町の概況

夜須町の町名の起源は、日本夆記によると、 神功皇后が朝廷に促わぬ甘木朝倉の強力な首 長を倒したのち、安堵感から、この地て「わ か心安し」と言われた「安」に由来している。 奈良時代に郡名が漢字二字に改められた時に、 その「安」が現在の「夜須」の名になったと 言われている。

夜須町は福岡市から南東 $25 \mathrm{~km}$ 、裍岡県の中 央部に位豈し、昭和 57 年現在、面秷 $45.4 \mathrm{~km}$ 、 世帝数2,598、人口12,610、全面積の30\%か 耕地て米作中心の喪業をんている。同町の 昭和 53 年 57 年の訂正死亡率とSM R 全国 と比較してみると、全死因ては全国と有意差 を㑇めなかったが、主要疾患別死亡について みると、全国にくらへて、男女共に肺炎・気 管支炎、男て不䖒の事故、女て高血圧性疾患 加有意に多い。

夜須町て、最も量業世帯の多い三並地区を 重点対象地区とした。この地区の人口 2,200 (内20才以上の対象人口は 1,090 )、対象世帯 数 402 、専素量家 $20.1 \%$ 、兼業家 $46.8 \%$ 、
会長江渏廣次（福岡大学医学部教授）

非晨家 $33.1 \%$ (内、常用勤労世帯 $10.0 \%$ 、自 営業・職人世帯 $10.2 \%$ 、その他 $12.9 \%$ ）で る。

1982年から5 年間は毎年、その媵1991年に 10年目の健康部查を実施した。全員に心電図 眼底检查を含めた湌診を行った。健康教育、 健康相秋、事後指導など十分に行った。

III. 保揵推進坫碚会の設立と組織

昭和 45 年に夜須町保健推進坳識会が設置さ れ、地域保揵活動の推進母体となった。医師 を会長に、食生活改善、学校保健、成人病対 策、広報の 4 部会をもち、每月第3 金晤日に 定列会を開催して活発な活動を展開している。 なお年 1 回町あげての健康まつりを開催して いる。

\section{IV. 一般住民の健康晾断}

昭和 56 年度から平成 3 年度まての結核健影 は、昭和 61 年度まて $80 \%$ 台で推移していたか その後、受㟝率は低下し $50 \%$ 程度になってい る。老人保健法に上る基本健康祅査は 20 才以 上の者に対して実施し、昭和 56 年 $19.0 \%$ て ったが年々受部率が向上し平成 3 年度は 49.6 \%に達している。がん湌部の受部率は、平成 3 年度には、胃汃ん32.2\%、子宮汃ん $48.5 \%$ 乳が $35.8 \%$ をし、全国の受衫率とくらへ て高率でる。

V.三並地区住民健康管理について

1. 受祅率の動向

10 年間の追跡て年平均の受祅率を算出した。 㖘家男 $37.9 \%$ 、女 $48.7 \%$ 、非晨家男 $29.2 \%$ 女 $37.1 \%$ (以上年龄㒥)でり、男女とも 


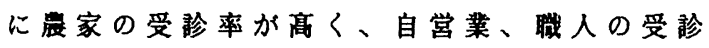
率か低かった。年龄階級別には40〜69才が高 率でった。

2. 1982 年からの 5 年間の健晾結果の特徽 三並地区の保健問題として、(1)中高年男性 の肥满が多い。(2)婦人の资血が多い。(3)高血 圧が多いことが挙げられた。1982年と86年を 比較してみると、中高年男性の肥满と婦人の 资血については、改善が殆ど認められなかっ たか、高血圧については、著名な改善が認め られ減塩指導を中心とする高血圧対策が满足 すへき効果を上げていた。

3.震業従事者と非震業従事者の生活習惯、 血清轱コレステロール（TC）の比較

男女639名のデー夕を農業说事の有無によ り 2 群に分けて湌討した。(1) T C、HDLの レベル：全国レベルと大差なし。非晨の T C が男女とも、晨に比へて高い傾向、H D L は 農が高い傾向を示していた。(2)生活習情：四 つの生活習惯について、一般に好ましくない と考えられる習情の類度をとって捈即した。 農に多量飲酒者及び多量喫煙者がやや多く、 運動しない人は非震にやや多い傾向がみられ た。肥满者は農・非農ともに女より男の方に 多かった。全国レベルと大差ない。(3) 4 年後 の変化：TCは男女、農・非曟ともに明らか な上昇を認めたがH D L レベルの上昇はわず かであった。肥满傾向はかなり增大し、男で は晨にその傾向がやや多かった。

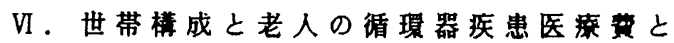
の関係

国保に加入している65才以上の老人につい

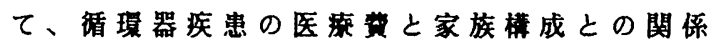
を調査した。子供と同居している場合、配偶 者のいる老人は、男女ともに医療費汃低かっ たか、配偶者のいない老人は、男女ともに医 療鿓高かった。子供と别居している場合、 配偶者のいる老人は男で入院医療弤低いか、 女ては逆に高かった。子供と別居し配偶者の
ない場合、男は入院が多く、入院外が少ない 傾向にあるか、女はその逆を示していた。一 人幕らし老人の場合、男女ともに医㩧費加低 い傾向にあった。

VI. 临環器疾患死亡者の調查

$1982-85$ 年、䛻環器疾患死亡者 134 名を症 例とし、性、年齡をマッチさせた生存者 268 名について調查を行った。risk factorにつ いては省略。(1)检診の受㟝状況：5年間検診 を受けていない割合は、男女とも症例が有意

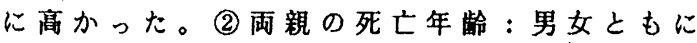
症例の実父実母か、対照のそれょり短命の傾 向がみられるが、有意差は男の実母のみにみ られた。(3)問題点のあった者：受診のおくれ は20〜69才死亡者に多く、高血圧者は男女共 に半数以上に認められ、治㞠を中断したり、 微底を欠く者は約 $20 \%$ 、生活面て酒、夕バコ、 食生活および安静などての医師の指示を守ら

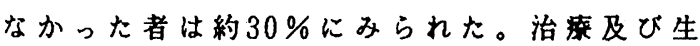
活面て問題のあった者は中年死亡者に多かっ た。

\section{И、まとめ}

福网県夜須町三並地区を中心にした健康管 理のあゆみを報告したが、九州の平地啝作㖘 村の姿をとらえたつもりである。健康診断の 受部率は、男、20〜39才、自営業、職人が低 い。高血王対策は成功したか、肥海、血清脂 啠については增加傾向が続いている。農業従 事者・非農業说事者間における生活習情と血 清脂算との関係は大差なく、その生活態様に は本筫的差異がなくなってきたという考えを いだいている。老人の医償については世帯 椿成との関係が強く、子供との同居の有無よ

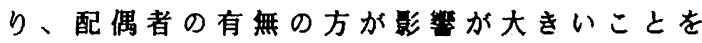
指摘てきたと思う。婂㻴器疾患死亡の分析て は、生活管理、检診、治㽷の面て重要な示惨 を得ることが出来た。今後とも厜村地域健康 分野の研究を続けたいと思っている。 


\title{
西海島嶼における人類生態系と健康像
}

\author{
竹本 泰一郎（長崎大・医・公采衛生）
}

I. はじめに

海洋による陌䎦と狭险な陸土を特徽とした島鲃ては、生活圈が島内や 近詸の島に限定されることが多く、自然・地理的条件や人間居住の歴 史によって、それぞれの島㟪に特徽的な人間一摆境系が形成される。 対馬、壱岐島から五島列島、天草列島をへて酤島にいたる西海島嶼群 は古くからの人間居住地であるとともに、大陸との海の交通の要地で もあった(図1)。また、中世におけるキリスト教の布教活動が盛んな地 㳦でもあった。現代では沿岸岛嶼群で産炭が盛んであったことも特徽 の一つである。本報告ては長崎県下の西海禹嶼について、人間居住の 経精と社会文化的背景による岛の人間理境系の特微がとように人口 の維持や人々の健康像を修飾しているかについて検討を試みたい。 II. 西海岛鲃群の人間一壦境系

1.自然と産業

広大な海域に散在する岛々の地理的条件や地势はそれぞれ異なる。 いわゆる大離岛である対馬岛、売岐息、上五岛の中通岛、下五島の福 江岛のうち、広い平坦地があるのは壳岐㗐と福江島であり、対馬岛と 中通岛は峻除な山々が運なり鹿菜通地は少ない。従って全岛鲃で農業 従事者は17\%に過をない。周囲を海に囲まれ対馬暖流の影非を受ける本 海域はわが国屈指の好漁場として知られており、留業道地の少ない大 䜅岛や中小島㟪では沖合・沿岸漁業が基幹産業であり、漁業従事者も

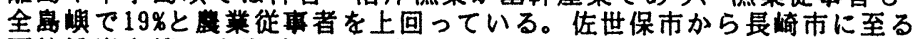
西彼沿㞥岛㟪山産炭地として盛んであったか、1960年代以降の相次ぐ 閒山によって現在も採炭を行っているのは 1 身のみである。

\section{2.人口}

長崎県下の 600 余の島のうち、人が常住している島は1955年には107て あったが本土との架棈・埋め立てによる本土化と無人化によって現在 (1990年)では75曷に遇它ない。人口は1955年には45万と全県人口の $27.4 \%$ を占めていたが現在は27万、17\%と減少偭向が大きい。特に旧炭 坑島舆の多い西彼杵半岛加長崎半島の沿岸の島で恢坑閒山による 無人岛化や人口減少が著しい（図2）。こうした就学・痽用機会を求め ての若壮年局を主体とした人口の流出によって島の人口の年路楼造は 高此化が急速に進展しており、全県の老年人口割合が14.7\%なのに対し て島の市町村、特に旧炭坑島舆では30\%を超すところも多い(1995年)。 また、世帯規模も細分化が進み、本土に比べて世帯人数が小さく、单 独世帯や核世带の割合が高い

3. 社会文化環境

16世紀にフランシスコザヒエルが平戸でキリスト教の布教を初めて 以来、キリス卜教信者が多いことが西海島鲃の文化面の特徽である。 江戸時代の禁教によって、多くは㯖れキリシタンとなり、島の辺境の 地に移住したことが現在の岛嗗の人間居住の端楮となったところも多 い。現在では長崎県下の全カソリック信者約74,000人のうち約 25.000 人が岛の居住者である(四了）。

III. 人類生態系と健康像の交䅂

1. 健康像の特徽

心磄や病や脳血管疾患による死亡率には本土や他県と比べて大きな差

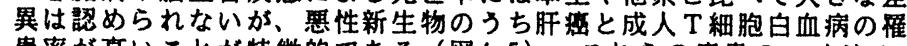
患率が高いことが特徽的である(図4.5)。これらの疾患のハイリスク であるそれそれの腫程ウイルスーB型肝炎ウイルス(HBV)とヒトT細胞 リンパ腫ウイルス (HTLV-1)の感染者が島嶼に多いことが知られている。 同時に、これら両ウイルスの感染流行に大をな地域差加存在している。 2. 腹動ウイルスの流行と人口移動、宗教:HBVとHTLV-1は共に垂直（母

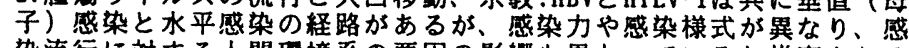
染流行に対する人間理境系の要因の影障も異なっていると推察される。

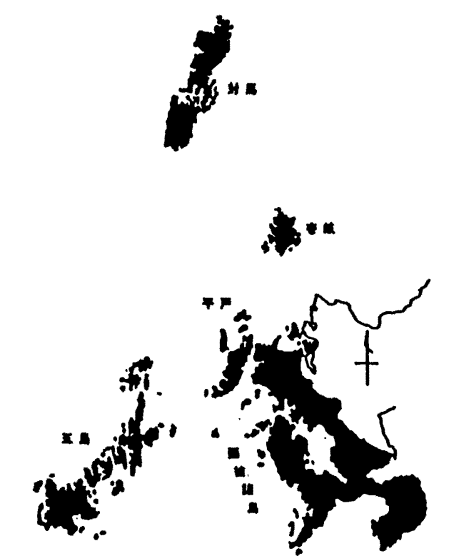

図1.長崎県下の西海岛嶼
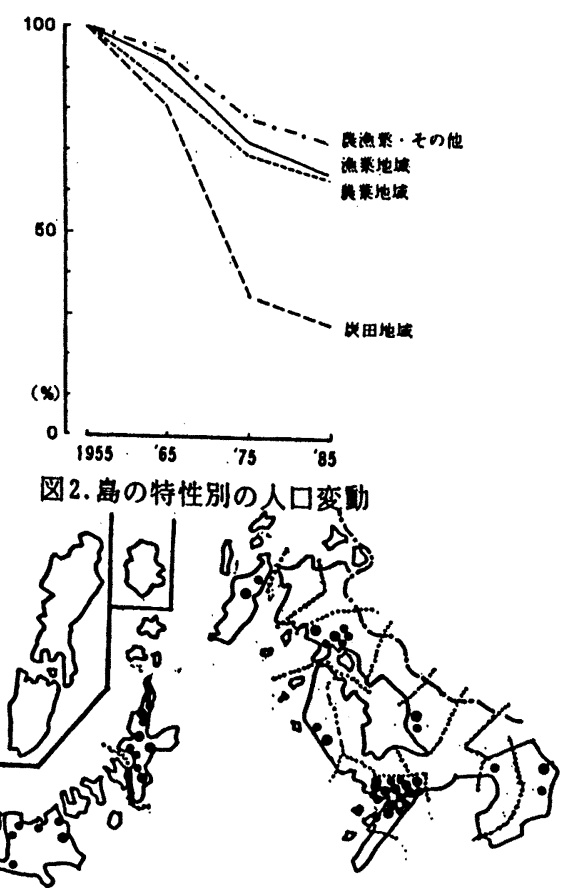

困3.カトリック教区

数徒数：・1000人以上、・1000人末渵 
特にHTLV-1については、西海島㒜で高流行であることについて ポルトガル人によるキリスト教伝来との関係や日本人の起源に まで遡る議論が交わされている。地理的条件とともに社会経済 的或は文化的背景の異なる島嶼 3 地域でこれらのウイルス流行 がどのように人口移動や宗教によって修飾されているかを検討 してみた。

対象のうち、壱岐 M地区は壱岐本島のから海路30分の主とし て沿岸漁業従事している小島嶼群であり、住民は全て仏教徒で ある。 $\mathrm{N}$ 町は上五島の主島である中通島のまき網漁業の基地で あり、16世紀に紀伊の漁師が定住を始めその後長崎本土カトリ ック地域等からの移住によつて発展してきた。対象者の $20 \%$ か クリスチャンである。西彼杵半島の沿岸島嶼である0島も16世 紀に始めての知行者の存在とその後の本土カトリック地域から の移住が記録されている。対象者の12\%がカトリックであった。 昭和初期から戦後まての炭鉱が存在したことによって、大きな 人口移動かみられたことが特徽である。HBs抗原・抗体の陽性率 からみると、HBs抗原抗体の陽性率は抗HTLV-1抗体のそれに比し て地域間差異が少なく、HBウイルスの流行が西海島嶼群で古く から広く流行していたことが推察される(表1)。HTLV-1抗体は地 域間差異が大をく、壱岐 M地区で最も高く、次いで上五島のN 町で高く、沿岸島嶼の0島で最も低率であった。年齢別分布で は、高流行地である壱岐 $\mathrm{M}$ 地区と上五島 $\mathrm{N}$ 島では女性の陽性率 が年路が高いほと高率になる傾问が認められたが、○島では高 秢者で逆に低率であり、過去における流行状態が異なっていた ことが推測された。

出生地、宗教の影㳱はそれぞれのウイルスで島ごとに異なる 様相が認められた。出生地別では壱岐M地区の出生者でHBV陽性 率が有意に高かったが、他島では差異は認められず、宗教では $\mathrm{N}$ 町、0 島ともにカトリック信者でHTLV-1抗体陽性率が高い傾 向が認められた。出生地と宗教とを組会わせてみると、両対象 ともそれぞれの地域で出生したカトリック信者でカトリックで ない移住者でより高い傾向が認められた(表2)。

IV.まとめ

島嶼の人閪生態系は自然条件とともに、人間居住の歴史的経 緯や生業活動によって大きく修飾されている。人々の健康像も それぞれの島の人間生態系によって特徵的なものに分化してい く。本報で健康りスクとして取り上げたウイルス感染について も西海島嶼で特徴的な人々の移動と定住の経緯或は宗教がそれ ぞれの島嶼での流行像を修飾していることが示唆された。こう した社会経済的・文化的条件が゙のように人々の行動や生活環 境に影謷を与えてきかについては、今後更なる検討が必要であ ろう。 参考文献

1) 竹本 泰一郎：プライマリ・ケアと公衆衛生活動 日本公衛 誌 $34(10), 24-30(1987)$.

2) Takemoto.T..H. Sueta \& Y.Kase:An observation on natural history of 1 iver diseases in Nagasaki. Acta Med. Nagas aki.. 31(4) . 304-307 (1986).

3) 竹本泰一郎,鈴木継美、宮本 勉他: 島嶼人間居住圈の可能 性と限界 日産科学振䁍財団報告畫12.81-88 (1989)。

4) Goto, H. . T. Takemoto, K. Shigeto and T.Miyamoto: A Human ecological study on epidemics of HBV and HTLV-1 among islands in western Japan. Acta Med. Nagasaki.,34,28-31 (1990).

5) Goto, H. , T. Takemoto, T. Izumi, K.Moji.S. Hino \& T.Miyamoto Impacts of sociocultural condition on regional endemic of HTLV-1 and HBV among islands in southwestern Japan. Acta Med.Nagasaki., 36(1-4), 117-127(1991).
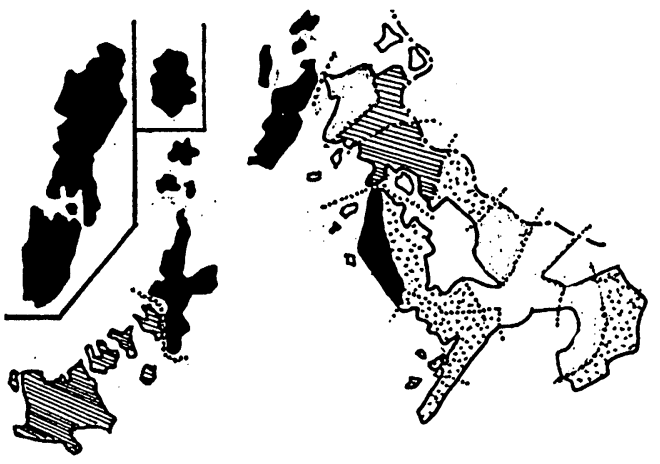

図4.肝癌の眻患率（年/人口10万対）

-15以上、 10-14、四9-5、士5未渵 （長崎県がん登録1985-' 89年）
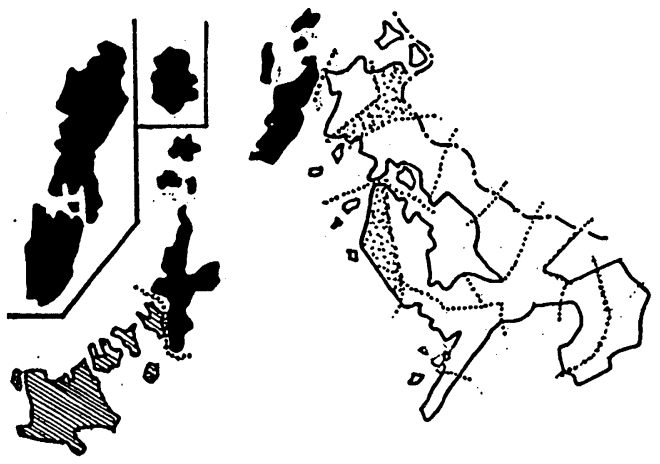

図5.成人 $\mathrm{T}$ 細胞白血病の䍜患率（年人口10万対）

10以上、9-7、两6-3、渵 (長崎県がん登録1985-' 89年)

\begin{tabular}{|c|c|c|c|c|c|c|}
\hline \multirow[b]{2}{*}{ 地域 } & \multicolumn{3}{|c|}{ HBV-marker ${ }^{\prime \prime}$} & \multicolumn{3}{|c|}{ Anti-HTL-1 } \\
\hline & M. & $\mathrm{F}$ & $M+F$ & $M$. & $\mathrm{F}$. & $M+F$ \\
\hline M & $\overline{56.8}$ & $\overline{57.0}$ & $\overline{56.8}$ & $\overline{40.2}$ & $\overline{45.3}$ & 43.8 \\
\hline $\mathrm{N}$ & 39.6 & 33.6 & 35.1 & 29.4 & 30.3 & 29.7 \\
\hline 0 & 27.6 & 34.2 & 31.7 & 10.5 & 14.5 & 13.0 \\
\hline
\end{tabular}

表1. 腫瘍ウイルス感染マーカーの陽性率 (\%) 1 ' $\mathrm{HBs} A \mathrm{~g}+\mathrm{HBsAb}$

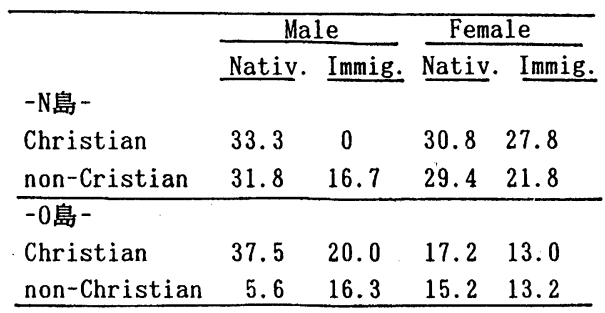

表2. 出生地、宗教別のAnti-HTLV-1抗体陽性率 (\%) Nativ. : 同島出生者、Immig: 島外出生者 